\title{
Perencanaan Instalasi Pengolahan Air Limbah Domestik di Kecamatan Simokerto Kota Surabaya
}

\author{
Ragil Tri Setiawati dan Ipung Fitri Purwanti \\ Jurusan Teknik Lingkungan, Fakultas Teknik Sipil dan Perencanaan, Institut Teknologi Sepuluh Nopember (ITS) \\ Jl. Arief Rahman Hakim, Surabaya 60111 Indonesia \\ e-mail:purwanti@enviro.its.ac.id
}

\begin{abstract}
Abstrak-Pada Kecamatan Simokerto tercatat 1.186 kepala keluarga atau sekitar $26,6 \%$ masih membuang air limbah domestik (black water dan grey water) langsung ke badan air atau saluran drainase tanpa ada pengolahan. Kondisi sanitasi di Kecamatan Simokerto dapat dikatakan belum sesuai dengan target Rencana Pembangunan Jangka Menengah Nasional (RPJMN) tahun 2015-2019, salah satunya yakni $100 \%$ sanitasi yang layak. Oleh sebab itu, perlu adanya upaya perbaikan sanitasi yakni merencanakan instalasi pengolahan air limbah domestik (black water dan grey water) di Kecamatan Simokerto dan biaya yang dibutuhkan.

Instalasi pengolahan air limbah domestik yang digunakan untuk Kecamatan Simokerto, yakni Anaerobic Baffled Reactor (ABR). Perencanaan ABR berdasarkan pada kebutuhan lahan, pembangunan, pengoperasian, perawatan, biaya investasi, dan efisiensi. Penentuan debit air limbah berdasarkan hasil survei yakni 146 liter/orang/hari dan kualitas air limbah domestik BOD, COD, TSS, dan pH yang digunakan dalam perencanaan yakni $494 \mathrm{mg} / \mathrm{l}, 799 \mathrm{mg} / \mathrm{l}, 473 \mathrm{mg} / \mathrm{l}$, dan 6,8 dengan kapasitas pengolahan untuk $100 \mathrm{KK}$.

Anaerobic Baffled Reactor (ABR) yang direncanakan memiliki 6 kompartemen dengan diameter pipa inlet $110 \mathrm{~mm}$. Dimensi panjang, lebar, dan kedalaman ABR yakni 13,2 meter, 2,6 meter, dan 2,6 meter. Biaya yang dibutuhkan dalam pembangunan ABR ini adalah sebesar Rp. 173.700.000,00.
\end{abstract}

Kata Kunci-Anaerobic Baffled Reactor, Air Limbah Domestik, Kecamatan Simokerto, Sanitasi

\section{PENDAHULUAN}

$\mathrm{K}^{\mathrm{s}}$ ECAMATAN Simokerto merupakan salah satu Kecamatan di Kota Surabaya yang memiliki kepadatan penduduk tertinggi. Berdasarkan data Badan Pusat Statistik Kota Surabaya tahun 2015, kepadatan penduduk Kecamatan Simokerto pada hasil sensus penduduk tahun 2010 yakni $30.571 \mathrm{jiwa} / \mathrm{km}^{2}$. Kepadatan penduduk tinggi disebabkan oleh peningkatan jumlah penduduk yang tidak diiringi dengan bertambahnya luas wilayah. Akibatnya kepadatan penduduk tinggi menyebabkan menurunnya kualitas lingkungan [1]. Hal ini terbukti bahwa berdasarkan Laporan Studi EHRA (Environmental Health Risk Assessment) Kota Surabaya 2010, Kecamatan Simokerto berada pada kluster 4 (area beresiko tinggi) terhadap kesehatan lingkungan dan rawan sanitasi.

Bedasarkan data Puskesmas Tambakrejo dan Simolawang (2015), bahwa di Kecamatan Simokerto tercatat 1.186 kepala keluarga atau sekitar 26,6\% yang masih membuang air limbah domestik (black water dan grey water) langsung ke badan air atau saluran drainase tanpa ada pengolahan terlebih dahulu. Apabila jumlah air limbah domestik (black water dan grey water) yang dibuang berlebihan, melebihi dari kemampuan alam untuk menerimanya, maka akan terjadi kerusakan lingkungan [2] dan dapat meningkatkan potensi masyarakat terkena penyakit diare dan demam berdarah [3]. Berdasarkan data Dinas Kesehatan Kota Surabaya tahun 2013 di Puskesmas Tambakrejo dan Simolawang tercatat 2.213 orang yang terkena penyakit diare dan 45 orang terkena penyakit demam berdarah. Penanggulangan penyakit diare dan demam berdarah dapat dilakukan dengan upaya perbaikan sanitasi [4]. Hal ini juga belum sesuai dengan target Rencana Pembangunan Jangka Menengah Nasional (RPJMN) tahun 2015-2019 yakni $100: 0: 100$, dimana 100\% dalam pelayanan air bersih, $0 \%$ kawasan permukiman kumuh, dan 100\% sanitasi yang layak. Oleh karena itu, pentingnya upaya perbaikan sanitasi dalam pemenuhan salah satu target RPJMN 2015-2019 maka dilakukan perencanaan Instalasi Pengolahan Air Limbah (IPAL) domestik di Kecamatan Simokerto Kota Surabaya.

\section{METODOLOGI PERENCANAAN}

\section{A. Ide Perencanaan}

Ide perencanaan didapatkan dari kondisi realita di Kecamatan Simokerto, dimana kondisi realitanya tidak sesuai dengan kondisi ideal yang direncanakan oleh pemerintah. Kondisi realita di Kecamatan Simokerto tercatat 1.186 Kepala Keluarga atau sekitar 26,6\% yang membuang air limbah domestik (black water dan grey water) ke saluran drainase tanpa adanya pengolahan, sedangkan pada kondisi idealnya adalah saluran drainase harus bebas dari air limbah domestik dan salah satu target dari RPJMN 2015-2019 yakni 100\% masyarakat memiliki sanitasi yang layak.

\section{B. Ruang Lingkup}

Ruang lingkup yang digunakan pada perencanaan ini adalah sebagai berikut:

1. Daerah studi perencanaan pada daerah BABS yakni sebagian warga RT 07 RW 05 Kelurahan Kapasan, sebagian warga RT 01 RW 01, RT 04 RW 09 dan RT 04,05,06,07 RW 03 Kelurahan Tambakrejo, dan sebagian 
warga RT 06 RW 02, RT 01,02 RW 03, RT 03 RW 04 Kelurahan Simolawang Kecamatan Simokerto. Daerah pelayanan dapat dilihat pada Gambar 1 .

2. Air limbah yang diolah yakni grey water dan black water.

3. Parameter yang digunakan BOD, COD, TSS, dan $\mathrm{pH}$.

4. Baku mutu efluen air limbah domestik yang digunakan sesuai dengan Peraturan Gubernur Jawa Timur Nomor 72 Tahun 2013 pada Lampiran III poin 4 tentang baku mutu air limbah domestik, rumah makan, perkantoran, perniagaan, apartemen, perhotelan, dan asrama.

5. Aspek yang ditinjau adalah aspek teknis dan aspek biaya..

6. Desain tipikal bangunan pada perencanaan yakni untuk 100 KK.

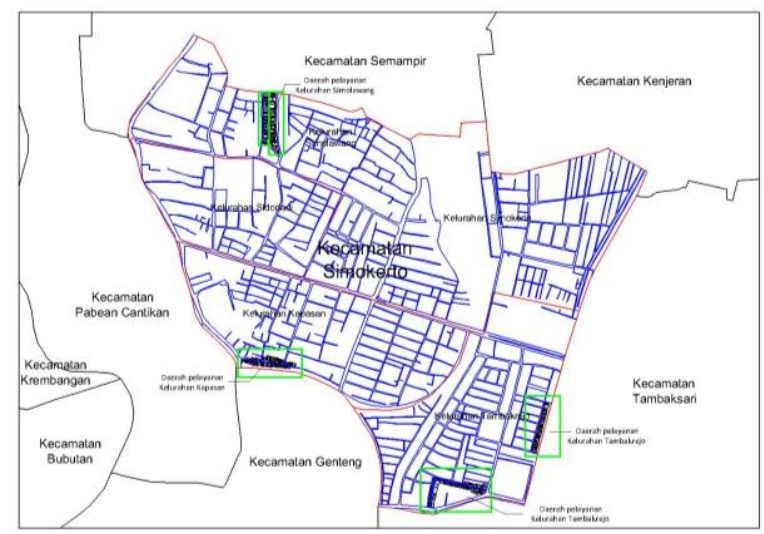

Gambar 1. Lokasi wilayah perencanaan

\section{Pengumpulan Data}

Data yang digunakan dalam perencanaan IPAL di Kecamatan Simokerto adalah data primer dan data sekunder. Data primer yakni meliputi survei lapangan, karakteristik air limbah domestik wilayah perencanaan (black water dan grey water), dan wawancara warga wilayah perencanaan mengenai kuantitas dan kegunaan air bersih. Penentuan jumlah responden mengacu Peraturan Menteri Pekerjaan Umum Nomor 18 Tahun 2007 tentang Tata Cara Survei yakni menggunakan rumus sebagai berikut:

$$
\begin{aligned}
& n=\frac{N p(1-p)}{(N-1) D+p(1-P)} \\
& D=\frac{B^{2}}{t^{2}}
\end{aligned}
$$

Dimana:

$\mathrm{n} \quad=$ Jumlah sampel

$\mathrm{N} \quad=$ Jumlah penduduk yang dilayani

$\mathrm{P} \quad=$ Rasio dari unsur dalam sampel yang memiliki sifat yang diinginkan $(\mathrm{P}=0,5)$

$\mathrm{B}=$ Bound of Error (tingkat kesalahan tiap sampel)

$\mathrm{t} \quad=$ Tingkat kepercayaan

Data sekunder yang digunakan meliputi data jumlah penduduk, peta wilayah perencanaan, kondisi eksisting sanitasi (Buang Air Besar Sembarangan), dan HSPK Kota Surabaya 2015.

\section{HASIL PERENCANAAN}

\section{Proyeksi Penduduk Wilayah Perencanaan}

Pada daerah perencanaan memungkinkan terjadinya pertumbuhan penduduk secara vertikal, sehingga pada perencanaan ini menggunakan proyeksi penduduk selama lima tahun ke depan menggunakan metode Least Square. Tujuan proyeksi penduduk untuk mengetahui jumlah pertumbuhan penduduk pada daerah pelayanan. Hasil proyeksi penduduk yang dilayani di Kelurahan Kapasan pada tahun 2020 adalah 285 jiwa, Kelurahan Tambakrejo adalah 1.318 jiwa, dan di Kelurahan Simolawang adalah 761 jiwa.

2. Debit Air Limbah Domestik

Penentuan debit air limbah domestik didapatkan dari hasil wawancara. Berdasarkan metode survei, jumlah responden yang digunakan dari $419 \mathrm{KK}$ BABS (1KK terdiri dari 5 orang) yang dilayani adalah $55 \mathrm{KK}$. Hasil wawancara responden menujukkan bahwa $67 \%$ responden menggunakan air PDAM sebagai sumber air bersihnya dengan pemakaian rata-ratanya 172 liter/orang/hari. Pemanfaatan air bersih yakni untuk MCK, air minum, masak, dan sebagian kecil untuk usaha. Pada perencanaan ini, air limbah domestik yang diolah yakni berasal dari kegiatan MCK, sehingga diasumsikan air limbah yang dihasilkan adalah $85 \%$ dari air bersih yang digunakan.

3. Kualitas Air Limbah Domestik

Kualitas rata-rata air limbah domestik yang diambil tiap 1 minggu sekali selama 3 minggu berturut-turut pada daerah perencanaan di Kecamatan Simokerto adalah sebagai berikut:
- $\mathrm{BOD}=494 \mathrm{mg} / \mathrm{l}$
- $\mathrm{COD}=799 \mathrm{mg} / \mathrm{l}$
- $\mathrm{TSS}=473 \mathrm{mg} / \mathrm{l}$
- $\mathrm{pH} \quad=6,8$

\section{Desain ABR}

Desain perencanaan ABR menggunakan rumus perhitungan yang mengacu pada literatur [5]. Kriteria desain yang digunakan untuk merencanakan ABR yakni sebagai berikut:

- Organic Loading Rate (OLR) $\quad=<3 \mathrm{Kg} \mathrm{COD} / \mathrm{m}^{3}$. hari

- Hydraulic Retention Time $(\mathrm{HRT})=>8 \mathrm{jam}$

- Kecepatan aliran (Vup) $\quad=<2 \mathrm{~m} / \mathrm{jam}$

- Panjang kompartemen $\quad=50 \%-60 \%$ kedalaman $\mathrm{ABR}$

Pada perencanaan ini direncanakan unit ABR sebagai berikut:

- Jupqah penduduk = 500 jiwa

- Debit air limbah total $=73,1 \mathrm{~m}^{3} /$ hari

- Waktu pengaliran $=24 \mathrm{jam}$

- Waktu pengurasan $\quad=2$ tahun

- Lebar unit ABR = 2 meter

- Kedalaman air $\quad=2$ meter

- Panjang kompartemen $=1,2$ meter

- Jumlah kompartemen $=6$ buah

- Temperatur air limbah $=28^{\circ} \mathrm{C}$

- Rasio SS/COD =0,42 (kriteria desain 0,35-0,45)

Unit ABR terdiri dari tangki pengendap dan kompartemen. Perhitungan efisiensi removal kedua bagian tersebut yakni sebagai berikut:

a. Tangki pengendap ABR

Tangki pengendap pada unit ini memiliki panjang 4,5 meter. Penentuan panjang tangki pengendap berdasarkan faktor debit 
air limbah tiap hari, pengurasan, konsentrasi BOD, waktu tinggal air limbah, dan laju akumulasi lumpur. Selanjutnya dilakukan perhitungan efisiensi removal COD yang dapat diketahui dari Gambar 2 dengan menggunakan HRT di tangki pengendap. Berdasarkan Gambar 2 didapatkan nilai faktor removal COD adalah 0,4 yang selanjutnya dikalikan dengan rasio SS/COD kemudian dibagi 0,6, maka efisiensi removal COD di tangki pengendap unit ABR ini sebesar $28 \%$.

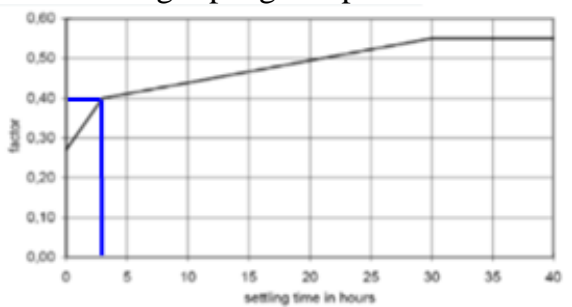

Gambar 2. Faktor COD removal dengan HRT

Efisiensi removal BOD di tangki pengendap dapat diketahui dari Gambar 3 dengan menggunakan persentase removal COD. Berdasarkan Gambar 3 didapatkan nilai faktor BOD removal adalah 1,06 yang selanjutnya dikalikan dengan persentase removal COD, maka efisiensi removal BOD di tangki pengendap unit ABR ini sebesar 30\%.

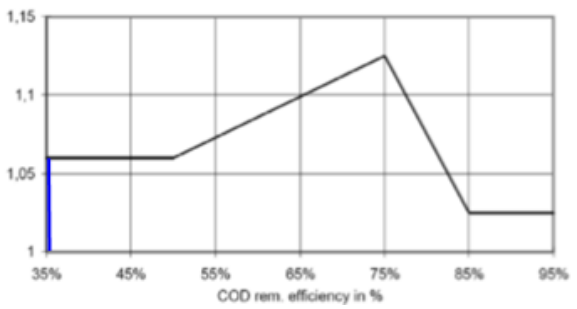

Gambar 3. Faktor BOD removal dengan COD removal

b. Kompartemen ABR

Konsentrasi COD dan BOD yang masuk ke kompartemen adalah $575 \mathrm{mg} / \mathrm{l}$ dan $348 \mathrm{mg} / \mathrm{l}$. Perhitungan efisiensi COD kompartemen didapatkan dari hasil perkalian empat faktor, yakni faktor overloading, faktor strength, faktor temperatur, dan faktor kompartemen. Penentuan nilai faktor overloading dapat diketahui dari Gambar 4 dengan menggunakan OLR BOD yang masuk ke kompartemen. OLR yang masuk ke kompartemen adalah $0,882 \mathrm{~kg} / \mathrm{m}^{3}$.hari. Berdasarkan Gambar 4 didapatkan nilai faktor overloading nya adalah 1 .

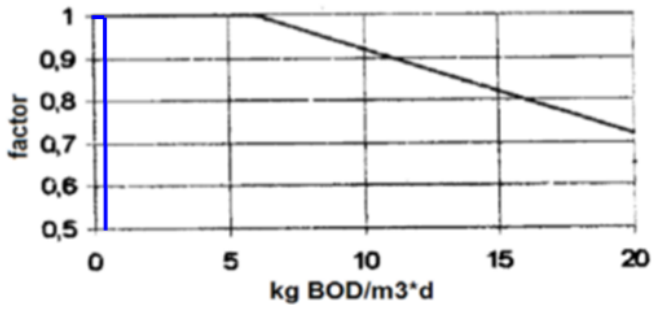

Gambar 4. Faktor overloading

Penentuan nilai faktor strength dapat diketahui dari grafik pada Gambar 5 dengan menggunakan konsentrasi BOD (mg/l) yang masuk ke kompartemen ABR. Konsentrasi BOD yang masuk ke kompartemen adalah $348 \mathrm{mg} / \mathrm{l}$. Berdasarkan Gambar 5 didapatkan nilai faktor strength nya adalah 0,89 .

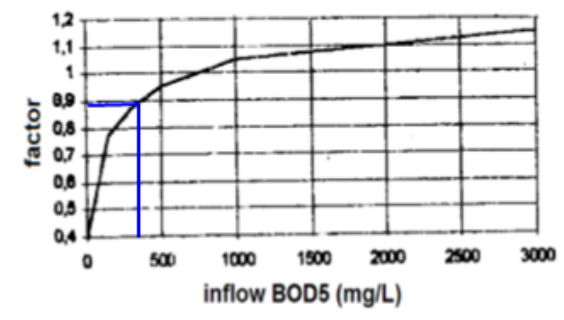

Gambar 5. Faktor strength

Penentuan nilai faktor temperatur dapat diketahui dari Gambar 6 dengan menggunakan temperatur air limbah domestik. Berdasarkan Gambar 6 didapatkan nilai faktor temperaturnya adalah 1,03 .

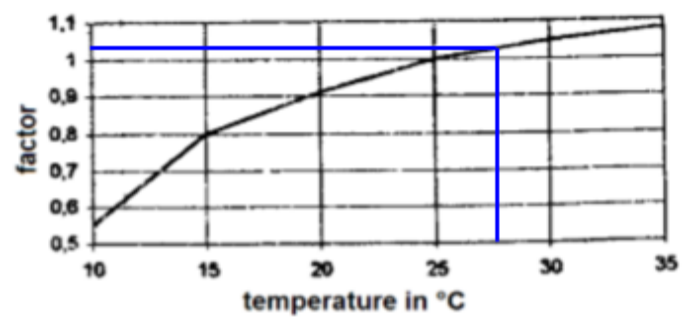

Gambar 6. Faktor temperatur

Penentuan nilai faktor kompartemen dapat diketahui dari Gambar 7 dengan jumlah kompartemen yang direncanakan. Berdasarkan Gambar 7 didapatkan nilai faktor kompartemennya adalah 1,08.

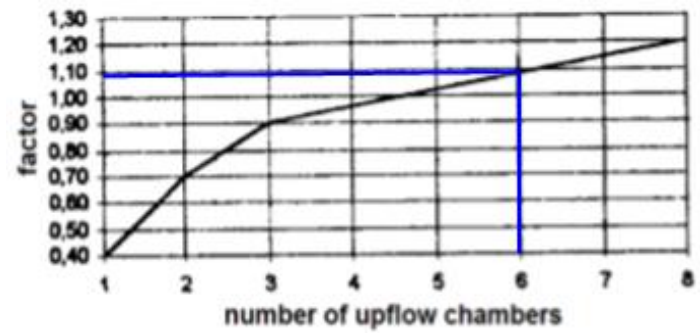

Gambar 7. Faktor kompartemen

Efisiensi removal COD di kompartemen ABR adalah 92\%, dimana total efisiensi removal COD pada IPAL adalah $94 \%$. Total efisiensi removal BOD pada IPAL dapat diketahui dari Gambar 8 dengan menggunakan total efisiensi removal COD pada IPAL dikalikan nilai faktor. Berdasarkan Gambar 8 didapatkan nilai faktornya adalah 1,025. Maka, total efisiensi removal BOD pada IPAL adalah 97\%, dimana efisiensi removal BOD pada kompartemennya adalah $95 \%$.

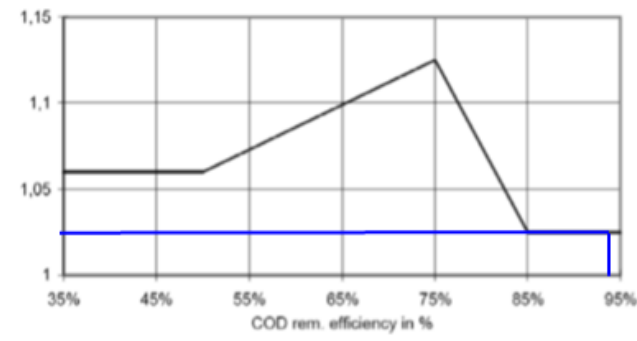

Gambar 8. Faktor rasio efisiensi BOD

Efisiensi removal BOD dan COD pada unit ABR menghasilkan kualitas efluen air limbah domestik yang memenuhi baku mutu sesuai dengan Peraturan Gubernur Jawa Timur Nomor 72 Tahun 2013. Jadi dimensi ABR yang didapatkan pada perencanaan ini adalah sebagai berikut:
- Lebar ABR
$=2$ meter 


$\begin{array}{ll}\text { - Kedalaman air di ABR } & =2 \text { meter } \\ \text { - Freeboard } & =0,3 \text { meter } \\ \text { - Panjang tangki pengenap } & =4,5 \text { meter } \\ \text { - Panjang tiap kompartemen } & =1,2 \text { meter } \\ \text { - Jumlah kompartemen } & =6 \text { buah }\end{array}$

Penentuan dimensi ABR tetap memperhatikan kriteria desain pada literatur [5], sehingga perlu dilakukan perhitungan nilai kecepatan aliran upflow (Vup), waktu detensi (HRT), dan beban organik COD (OLR) di kompartemen. Hasil perhitungan Vup, HRT, dan OLR COD adalah sebagai berikut:

- Kecepatan aliran (Vup) $\quad=1,27 \mathrm{~m} / \mathrm{jam}$

- Hydraulic Retention Time $(\mathrm{HRT})=$ 9,5 jam

- Organic Loading Rate (OLR) $\quad=1,46 \mathrm{~kg} \mathrm{COD} / \mathrm{m}^{3}$. hari

Tampak atas dan denah bangunan ABR dapat dilihat pada Gambar 9. Potongan memanjang (A-A) unit ABR dapat dilihat pada Gambar 10. Potongan melintang (B-B, C-C, dan D-D) unit ABR dapat dilihat pada Gambar 11.

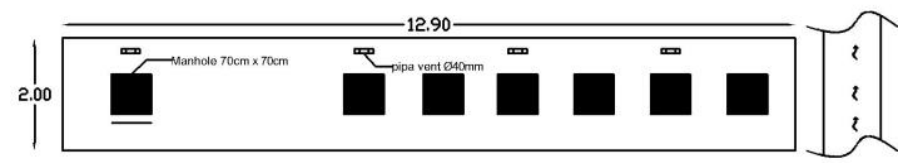

(a)

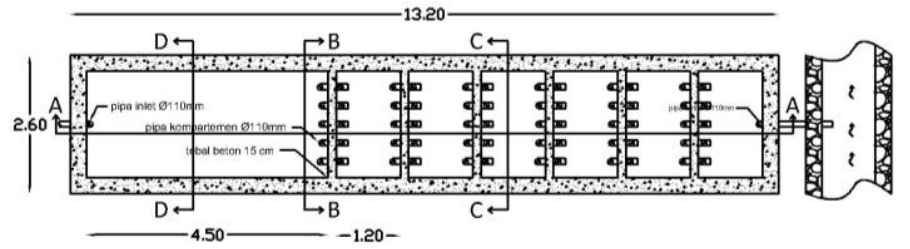

(b)

Gambar 9. Tampak atas ABR (a) dan denah ABR (b)

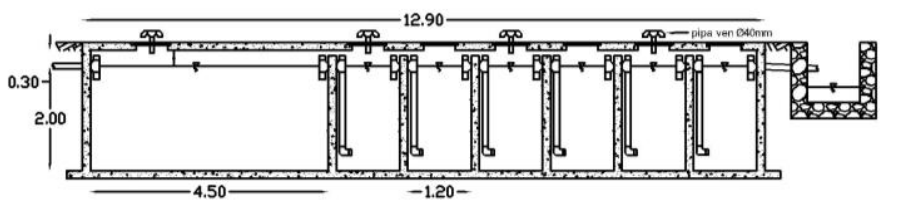

Gambar 10. Potongan memanjang ABR (a) B-B

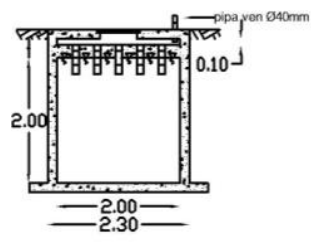

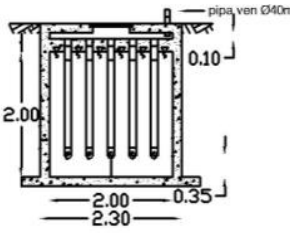

(b) $\mathrm{C}-\mathrm{C}$

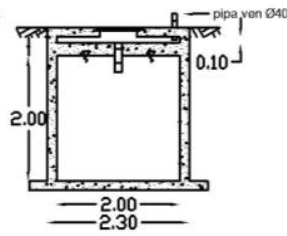

(c) D-D
Gambar 11. Potongan melintang ABR

\section{Perencanaan Lokasi Peletakkan ABR}

Perencanaan pembangunan ABR diletakkan di bawah jalan dan bahu jalan. Kelas jalan pada wilayah perencanaan berdasarkan beban kendaraan yakni kelas jalan III A, dimana muatan beban terberat yang diizinkan melintas adalah 8 ton. Berdasarkan kelas jalan, maka kekuatan beton yang digunakan dalam pembangunan ABR adalah beton K-200. Selain itu, pondasi yang digunakan merupakan jenis pondasi telapak yakni pondasi dari beton bertulang dimana ketebalan beton yang digunakan adalah 0,15 meter. Berdasarkan hasil survei lapangan, rencana lokasi peletakkan ABR pada Kelurahan Kapasan dapat dilihat pada Gambar 12, rencana lokasi peletakkan ABR pada Kelurahan Tambakrejo dapat dilihat pada Gambar 13. Rencana lokasi peletakkan ABR pada Kelurahan Simolawang dapat dilihat pada Gambar 14.
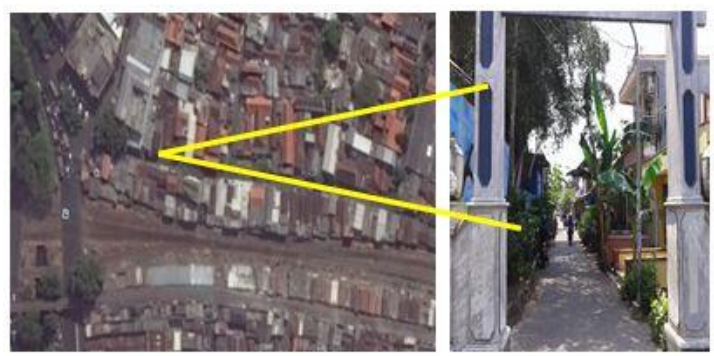

Gambar 12. Rencana lokasi peletakkan ABR di Kelurahan Kapasan
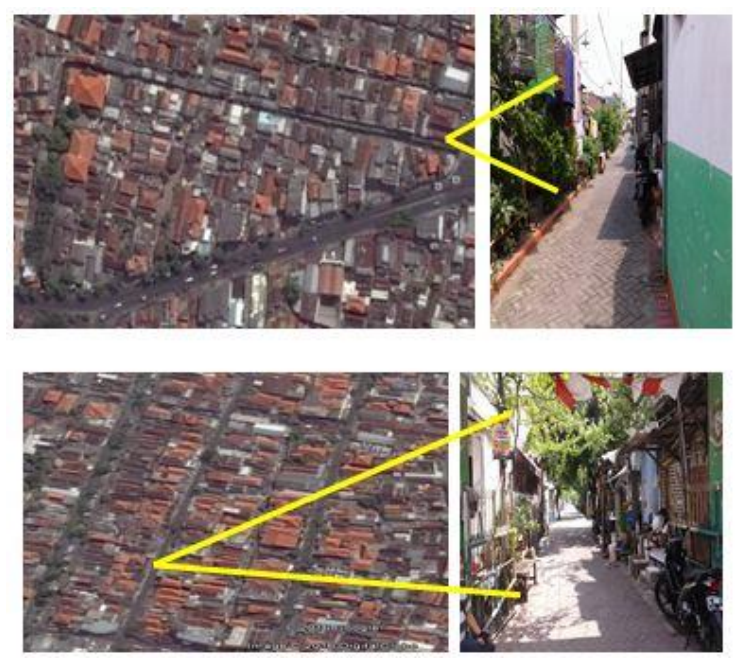

Gambar 13. Rencana lokasi peletakkan ABR di Kelurahan Tambakrejo

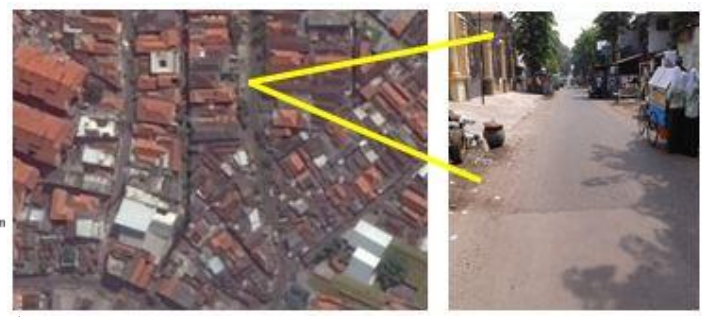

Gambar 14. Rencana lokasi peletakkan ABR di Kelurahan Simolawang

\section{RANCANGAN ANGGARAN BIAYA}

Rencana anggaran biaya pada perencanaan ini mengacu pada Harga Satuan Pokok Kegiatan (HSPK) Kota Surabaya 2015. Pada perencanaan pembanguan ABR dibagi menjadi 3 tahapan yakni tahap persiapan, tahap pekerjaan utama, dan tahap finishing. Ketiga tahapan tersebut mempunyai uraian kegiatan dan nilai HSPK. Berdasarkan nilai HSPK dan volume pekerjaan pembangunan $\mathrm{ABR}$, maka dapat diketahui total biaya yang dibutuhkan tiap pekerjaannya. Rincian biaya tiap kegiatan dan total biaya dalam pembangunan ABR dapat dilihat pada Tabel 1. 
Tabel 1.

Rancangan Anggaran Biaya

\begin{tabular}{|c|c|c|c|c|}
\hline No & Uraian Kegiatan & Satuan & \multicolumn{2}{|c|}{ Total Biaya (Rp) } \\
\hline \multicolumn{5}{|c|}{$\begin{array}{l}\text { Tahap Persiapan } \\
\end{array}$} \\
\hline 1 & $\begin{array}{l}\text { Pembersihan lapangan "ringan" dan } \\
\text { perataan }\end{array}$ & $\mathrm{m}^{2}$ & $\mathrm{Rp}$ & 406.404 \\
\hline 2 & $\begin{array}{l}\text { Pembongkaran paving yang tidak } \\
\text { dipakai kembali }\end{array}$ & $\mathrm{m}^{2}$ & $\mathrm{Rp}$ & 162.562 \\
\hline 3 & $\begin{array}{l}\text { Pengukuran dan pemasangan } \\
\text { bouwplank }\end{array}$ & $\mathrm{m}^{2}$ & $\mathrm{Rp}$ & 8.700 .624 \\
\hline \multicolumn{3}{|c|}{ Jumlah } & $\mathrm{Rp}$ & 9.269 .590 \\
\hline \multicolumn{5}{|c|}{ Tahap Pek erjaan Utama } \\
\hline 1 & $\begin{array}{l}\text { Penggalian tanah biasa untuk } \\
\text { konstruksi }\end{array}$ & $\mathrm{m}^{3}$ & $\mathrm{Rp}$ & 10.267 .452 \\
\hline 2 & $\begin{array}{l}\text { Pengangkutan tanah dari lubang } \\
\text { galian dalamnya lebih dari } 1 \mathrm{~m}\end{array}$ & $\mathrm{~m}^{3}$ & $\mathrm{Rp}$ & 2.093 .364 \\
\hline 3 & $\begin{array}{l}\text { Pekerjaan balok beton bertulang ( } 200 \\
\text { kg besi+bekisting) }\end{array}$ & $\mathrm{m}^{3}$ & $\mathrm{Rp}$ & 6.971 .319 \\
\hline 4 & $\begin{array}{l}\text { Pekerjaan kolom beton bertulang (150 } \\
\text { kg besi+bekisting) }\end{array}$ & $\mathrm{m}^{3}$ & $\mathrm{Rp}$ & 5.644 .492 \\
\hline 5 & $\begin{array}{l}\text { Pekerjaan dinding beton bertulang } \\
\text { (200 kg besi+bekisting) }\end{array}$ & $\mathrm{m}^{3}$ & $\mathrm{Rp}$ & 90.905 .196 \\
\hline 6 & Pekerjaan plat beton (1Pc:2 Ps:3Kr) & $\mathrm{m}^{3}$ & $\mathrm{Rp}$ & 29.350 .284 \\
\hline 7 & $\begin{array}{l}\text { Pemasangan pipa air kotor diameter } \\
4^{\prime}\end{array}$ & $\mathrm{m}$ & $\mathrm{Rp}$ & 4.636 .632 \\
\hline 8 & Pelapisan waterproofing & $\mathrm{m}^{2}$ & $\mathrm{Rp}$ & 12.365 .392 \\
\hline \multicolumn{3}{|c|}{ Jumlah } & $\mathrm{Rp}$ & 162.234 .131 \\
\hline \multicolumn{5}{|c|}{ Tahap Finishing } \\
\hline 1 & Pengurugan tanah dengan pemadatan & $\mathrm{m}^{3}$ & $\mathrm{Rp}$ & 1.410 .406 \\
\hline 2 & $\begin{array}{l}\text { Pembersihan lapangan dan perataan } \\
\text { tanah }\end{array}$ & $\mathrm{m}^{3}$ & $\mathrm{Rp}$ & 812.808 \\
\hline \multicolumn{3}{|c|}{ Jumlah } & $\mathrm{Rp}$ & 2.223 .214 \\
\hline \multicolumn{3}{|c|}{ Total } & $\mathbf{R p}$ & 173.726 .935 \\
\hline
\end{tabular}

Berdasarkan Tabel 1, maka rancangan anggaran biaya yang dibutuhkan untuk pembangunan ABR yang diletakkan dibawah jalan adalah Rp. 173.700.000,00. Adapun pembangunan $\mathrm{ABR}$ yang diletakkan dibahu jalan adalah Rp. 173.500.000,00. Perbedaan harga pembangunan di kedua lokasi tersebut yakni pada kegiatan pembongkaran paving.

\section{KESIMPULAN}

1. Perencanaan pengolahan limbah domestik di Kecamatan Simokerto digunakan Anaerobic Baffled Reactor (ABR). Unit ABR yang direncanakan yakni tipikal untuk setiap 100 KK yang terdiri dari tangki pengendap dan 6 kompartemen. Total panjang, lebar, dan kedalaman ABR adalah 13,2 meter, 2,6 meter, dan 2,6 meter.

2. Biaya yang dibutuhkan untuk pembangunan satu unit ABR di Kecamatan Simokerto yakni sebesar Rp. 173.700.000,00 (peletakkan di bawah jalan) dan Rp. 173.500.000,00 (peletakkan di bawah bahu jalan).

\section{DAFTAR PUSTAKA}

[1] Prameswari, RA. Prahastiwi. 2014. Perencanaan Pelayanan Air Limbah Komunal di Desa Krasak Kecamatan Jatibarang Kabupaten Indramayu. Skripsi. Fakultas Teknik Sipil dan Perencanaan, ITS. Surabaya.

[2] Wulandari, Puji Retno. 2014. Perencanaan Pengolahan Air Limbah Sistem Terpusat (Studi Kasus di Perumahan PT. Pertamina Unit Pelayanan III Plaju - Sumatera Selatan). Fakultas Teknik Sipil dan Perencanaan Universitas Sriwijaya, Volume 2 Nomor 3.

[3] Khairina, Nadfizah. 2015. Perencanaan Teknologi Sanitasi sebagai Upaya Bebas Buang Air Besar Sembarangan di Kecamatan Genteng. Skripsi. Fakultas Teknik Sipil dan Perencanaan, ITS. Surabaya.

[4] Umiati. 2009. Hubungan Antara Sanitasi Lingkungan dengan Kejadian Diare pada Balita di Wilayah Kerja Puskesmas Nogosaro Kabupaten Boyolali Tahun 2009. FKM Universitas Muhammadiyah. Surakarta.

[5] Sasse, Ludwig. 1998. Decentralised Wastewater Treatment in Developing Countries (DEWATS). Jerman: BORDA. 